\title{
Green Synthesis, Characterization and Antimicrobial Activity of Silver Nanoparticles from the Extract of Lagerstroemia speciosa
}

\author{
VINIT PRAKASH ${ }^{1 *}$, HARPREET KAUR ${ }^{1}$, ANJANA KUMARI ${ }^{1}$, MANOJ KUMAR ${ }^{1}$, \\ SUMEET GUPTA ${ }^{2}$ and RITU BALA ${ }^{3}$
}

\begin{abstract}
${ }^{1}$ Department of Chemistry, M. M. University, Sadopur-Ambala 134007, Haryana, India. ${ }^{2}$ M.M. College of Pharmacy, M. M. University, Mullana-Ambala 133203, Haryana, India. ${ }^{3}$ Department of Chemistry, Guru Nanak Dev University-Amritsar 143005, Punjab, India. ${ }^{*}$ Corresponding author E-mail: vinitprakash@gmail.com
\end{abstract}

http://dx.doi.org/10.13005/ojc/370318

(Received: April 19, 2021; Accepted: May 21, 2021)

\section{ABSTRACT}

Lagerstroemia speciosa is commonly known as Banaba or Jarul which is used to get rid of various ailments such as fever, urinary infection, decongestion, diarrhoea, mouth ulcers, astringent, diabetes mellitus, kidney diseases, abdominal pains etc. The present work, describes the green synthesis of silver nanoparticles from ethanolic extract of fruits of $L$. speciosa (Ls-Ag NPs) and their analysis for antimicrobial activities. The characterisation of so obtained nanoparticles have been carried out with help of Field emission scanning electron microscopy (FESEM) and High-resolution transmission electron microscopy (HRTEM). Further, antimicrobial activities of ethanolic extract of fruits of $L$. speciosa (Ee-Ls), silver oxide $\left(\mathrm{Ag}_{2} \mathrm{O}\right)$ and $\mathrm{Ls}-\mathrm{Ag}$ NPs have been examined by using well-diffusion method against two bacterial strains: Staphylococcus aureus (Gram-positive) and Escherichia coli (Gram-negative) and one fungal strain: Aspergillus niger. It has been observed that the biosynthesized Ls-Ag NPs possess much effective antimicrobial activity against selected strains as compared to Ee-Ls and $\mathrm{Ag}_{2} \mathrm{O}$.

Keywords: Lagerstroemia speciosa fruits, Silver nanoparticles, Green synthesis, Antimicrobial activity.

\section{INTRODUCTION}

Advances in synthesis of nanoparticles from various substances and their applications have led no research area to be remained untouched towards new verdicts day by day. Nanoparticles of different materials have shown broad applications in the field of synthesis, chemicals, pharmaceuticals, health care, optics, environmental, food, mechanical, manufacturing, materials industries and many more ${ }^{1-4}$. The shape and size of nanoparticles depends upon working strategies and methods of their synthesis (chemical, physical and biological) ${ }^{5-8}$. The chemical and physical methods are not environment friendly due to the use of toxic organic solvents, reducing/stabilizing agents; production of hazardous

This is an Open Access article licensed under a Creative Commons license: Attribution 4.0 International (CC- BY). Published by Oriental Scientific Publishing Company @ 2018

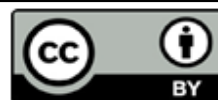


by-products and high energy consumption ${ }^{9-11}$. Green synthesis has been identified as one of the alternate to replace these methods because of its large quantity capability, eco-friendly, cost-effective, simple work procedure ${ }^{12-14}$.

Many researchers have proved that plants have effective potential towards green synthesis approach of metal nanoparticles ${ }^{15-17}$ because of secondary metabolites. The secondary metabolites include alkaloids, essential oils, flavonoids, phenols, terpenoids etc. ${ }^{18-20}$ and these act as reducing and capping agent for the formation of metallic nanoparticles ${ }^{21,22}$. The plant extract and its nanoparticles with metals (silver, gold, platinum, titanium, zinc, cerium, iron and thallium) have shown several biological activities such as anti-arthritic, antidiabetic, anti-inflammatory, antimicrobial, antinociceptive, anti-obesity, anti-oxidant, cytotoxicity and so on ${ }^{23-26}$. However, metal nanoparticle modification of crude extract has resulted into enhanced activity as compared to crude alone $e^{27-30}$.

Lagerstroemia speciosa is commonly known as Banaba, Jarul, Queen of flowers, Crepe myrtle, Pride of India, belongs to Lythraceae family having more than 50 species $^{31-33}$. Various parts of $L$. speciosa viz., fruits, leaves, bark, roots have been used as a traditional medicine to treat several diseases. The synthesis of nanoparticle from the fruits of this plant and study of their antimicrobial activities have not been reported till date. However, synthesis of silver ${ }^{34,35}$ and zirconium oxide nanoparticle ${ }^{36,37}$ from aqueous extract of L. speciosa leaves and analysis their antimicrobial, biofilm, photocatalytic and cytotoxicity activities ${ }^{34-37}$ have been carried out so far. In the present study, we have synthesized the silver nanoparticles from ethanolic extract of fruits of $L$. speciosa (contains reducing/stabilizing agent) through green synthesis method and have compared the activities of Ee-Ls, $\mathrm{Ag}_{2} \mathrm{O}$, and Ls-Ag NPs. Ag NPs are found to be better biologically active to that of Ee-Ls and $\mathrm{Ag}_{2} \mathrm{O}$.

\section{MATERIALS AND METHODS}

All the chemicals (ethanol, silver oxide and silver nitrate) have been purchased from SigmaAldrich. The Agar-agar powder, Nutrient broth, and Potato dextrose agar (Hi-media) were used for microbial culture. The standard drugs, Ciprofloxacin (for antibacterial) and Fluconazole (for antifungal) had purchased from Local Retail Pharmacy Shop.

\section{Plant materials}

The fruits of $L$. speciosa were collected from campus garden of Maharishi Markandeshwar University, Sadopur (Ambala) in October, 2018. The authentication of the plant has been confirmed from Department of Natural Products in National Institute of Pharmaceutical Education and Research (NIPER), Punjab, India. A voucher specimen number NIP-H275 has been preserved for further verification.

\section{Preparation of the extract}

The air-dried fruits $(1 \mathrm{~kg})$ have been extracted with ethanol $\left(60-70^{\circ} \mathrm{C}\right)$ by using a soxhlet apparatus for $72 \mathrm{~h}$ as per standard procedure ${ }^{38}$. After the completion of extraction, liquid was concentrated at $40-60^{\circ} \mathrm{C}$ by rotary evaporator till the saturated mixture obtained and then evaporated on a water bath at $40-50^{\circ} \mathrm{C}$ to gotten crude extract. The obtained crude extract (46 g) was kept in the refrigerator at $4^{\circ} \mathrm{C}$ in glass vials for further analysis.

\section{Secondary metabolites analysis of the Ee-Ls}

The secondary metabolites analysis of crude extract has been done by their specific confirmatory tests for alkaloids, carbohydrates, fat-oils, flavonoids, glycosides, phenols, proteins, saponins, steroids, tannins, and terpenoids ${ }^{39-41}$. The presence of alkaloids, carbohydrates, flavonoids, glycosides, phenols, steroids, tannins and terpenoids were shown in Table 1.

\section{Preparation of the Ls-Ag NPs}

Green synthesis method has been adopted to the preparation of Ls-Ag NPs. The reaction mixture was prepared by mixing $20 \mathrm{~mL}$ of ethanol extract with $180 \mathrm{ml}$ of $\mathrm{AgNO}_{3}(1.0 \mathrm{mM})$ solution in a $250 \mathrm{~mL}$ of the conical flask for reduction of $\mathrm{Ag}^{+}$to $\mathrm{Ag}^{0}$ ions. The mixture has been stirred continuously on the hot plate magnetic stirrer at $60-70^{\circ} \mathrm{C} 1$ hour. The colour of solution changed from pale yellow to dark brown, indicate the nanoparticles have been prepared ${ }^{34,37}$.

\section{Purification of nanoparticles}

To separate the non-metal components from the Ls-Ag NPs, coloured suspension was centrifuged at $6000 \mathrm{rpm}$ for 20 minute. The ethanol layer of prepared Ls-Ag NPs was collected carefully 
and dispersed with ethanol. This process was repeated thrice to separate the entities from metal nanoparticles. The centrifugation process was done by laboratory centrifuge (REMI India). To prevent the agglomeration of the ions, the purified solution of Ls-Ag NPs was kept for sonication after treating with ethanol for 10 minute $^{37}$.

\section{Characterization of the Ls-Ag NPs High-resolution transmission electron microscopy analysis}

The size and shape of the prepared LsAg NPs have been studied using High-resolution transmission electron microscopy. The sample has been carried out on an HRTEM, JEOL-2100 plus microscope, working at an acceleration voltage of $200 \mathrm{kV}$. It prepared by prior dispersion in ethanol at the appropriate concentration and placing a small drop of solution on a carbon-coated copper grid. After 2 min of deposition of the film on a TEM grid, the excess solution has been removed using a blotting paper and the grid was allowed to dry for overnight at room temperature to measurement.

\section{Field emission scanning electron microscope analysis}

The surface texture and morphology of the synthesis Ls-Ag NPs have been characterized by using Field emission scanning electron microscope, Hitachi FE 8010. A thin film of the sample has been prepared on a platinum-coated carbon tape by dropping a small amount of the sample on a grid, an extra sample has been removed, and then the film on the SEM grid was allowed to dry under a mercury lamp for 5 minute.

\section{Antimicrobial assay}

The antimicrobial analysis of the Ee-Ls, $\mathrm{Ag}_{2} \mathrm{O}$ and Ls-Ag NPs have been confirmed by welldiffusion method against selected Gram-positive (Staphylococcus aureus) and Gram-negative (Escherichia coli) bacteria as well as pathogenic fungus Aspergillus niger. For the culturing of bacterial and fungal strains, Nutrient broth (NA) and Potato dextrose agar (PDA) were used as media. Loops full of all the bacterial and fungus cultures were inoculated in nutrient at $37^{\circ} \mathrm{C}$ for $24-48 \mathrm{~h}$ and in potato dextrose at $27^{\circ} \mathrm{C}$ for $48-72$ hours ${ }^{43-45}$.

Through serial dilution method, different concentrations $(100,200,400 \mathrm{ppm})$ of samples
Ee-Ls, $\mathrm{Ag}_{2} \mathrm{O}$ and Ls-Ag NPs have been prepared in DMSO and compared with standard antibiotic Ciprofloxacin (100 ppm) for bacterial and Fluconazole (100 ppm) for fungal assay. The respective solvent (sterile DMSO) has been used as a negative control. The freshly prepared inoculums (108 CFU/mL) of each test bacterium spread on the sterile petri plates. The plates were allowed to dry, then four wells were bored having $7 \mathrm{~mm}$ diameter using sterile cork-borer and were labelled properly ${ }^{46}$. Subsequently, $40 \mu \mathrm{L}$ of each dilution were added in triplicate wells using microtiter-pipette and plates were allowed to stand at least $1 \mathrm{~h}$ for diffusion to take place. The plates were then incubated in an upright position at $37^{\circ} \mathrm{C}$ for $24 \mathrm{~h}$ for bacterial analysis and for fungal assay the plates have been incubated at $27^{\circ} \mathrm{C}$ for 72 hours. The results were evaluated by measuring the width of the zone of inhibition growth against the selected microorganisms in comparison with antibiotics (Ciprofloxacin and Fluconazole) and mean values were tabulated.

\section{RESULTS}

\section{Secondary metabolites analysis of the Ee-Ls}

In the present investigation, the secondary metabolites analysis has been done for Ee-Ls fruits by their specific confirmatory tests ${ }^{39-41}$. The presence of secondary metabolites are shown in Table 1.

Table 1: Secondary metabolites analysis of the Ee-Ls

\begin{tabular}{cc}
\hline $\begin{array}{c}\text { Phytochemical } \\
\text { Constituents }\end{array}$ & Ee-Ls \\
\hline Alkaloids & - \\
Carbohydrates & + \\
Fats/oils & - \\
Flavonoids & - \\
Glycosides & - \\
Phenols & + \\
Proteins & + \\
Saponins & + \\
Steroids & - \\
Tannins & + \\
Terpenoids & - \\
\hline+ ' indicates presence, '-' indicates an \\
absence
\end{tabular}

High-resolution transmission electron microscopy

High-resolution transmission electron microscopy performed to acquire the size and shape of the synthesized Ls-Ag NPs, shown in Fig. 1 (1a and 1b). The average particle size of Ls-Ag NPs was calculated around $50-60 \mathrm{~nm}$. The eclipsed shape of Ls-Ag NPs was appeared in the characterized TEM images. 


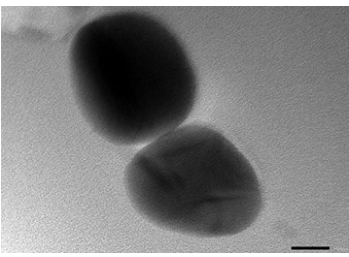

$1 \mathrm{a}$

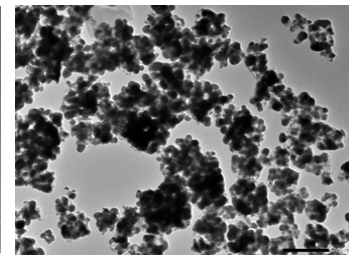

$1 \mathrm{~b}$
Fig. 1. HRTEM images of Ls-Ag NPs from Ee-Ls (a) scale $20 \mathrm{~nm}$, (b) scale $500 \mathrm{~nm}$

Field emission scanning electron microscope

The FESEM analysis explain the surface texture and morphology of the synthesis Ls-Ag NPs shown in Fig. 2. The microscope image prove that Ls-Ag NPs are in nanoscale range and have uniform distribution.

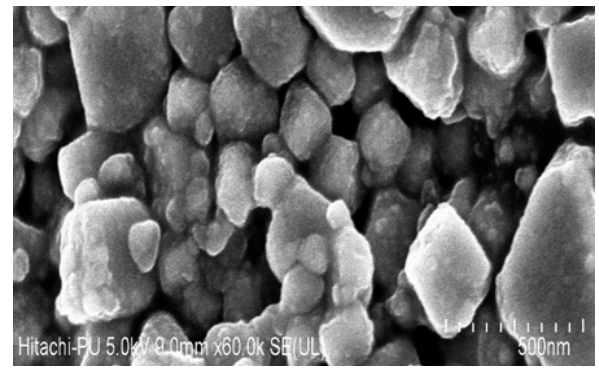

Fig. 2. FESEM image of Ls-Ag NPs from Ee-Ls; scale $500 \mathrm{~nm}$

\section{Antimicrobial activity}

In the presence study, the antimicrobial activity of synthesis Ls-Ag NPs compared with $\mathrm{Ag}_{2} \mathrm{O}$ and Ee-Ls at concentration (100, 200, 400 ppm) by well-diffusion method against Staphylococcus aureus (Gram-positive) and Escherichia coli (Gramnegative) bacterial strains and one fungal strain viz. Aspergillus niger. The Ee-Ls, $\mathrm{Ag}_{2} \mathrm{O}$, and Ls-Ag NPs inhibited the growth of all tested microorganisms with a zone of inhibition range from $0.9 \pm 0.1$ to $5.7 \pm 0.2 \mathrm{~mm}$, $3.62 \pm 0.2$ to $7.3 \pm 0.2 \mathrm{~mm}$ and $7.5 \pm 0.2$ to $10 \pm 0.2 \mathrm{~mm}$ for bacterial strains and fungal strain the range of zone of inhibition was $0.5 \pm 0.1$ to $3.4 \pm 0.2 \mathrm{~mm}, 1.5 \pm 0.2$ to $4.3 \pm 0.2 \mathrm{~mm}$ and $4 \pm 0.1$ to $6.1 \pm 0.1 \mathrm{~mm}$. The Ls-Ag NPs have been shown effective results against selected bacterial ( $E$. coli and $S$. aureus) and fungal strain (A. niger) shown in Table 2 and Fig. 3. The Ls-Ag NPs have been exhibited the maximum zone of inhibition against Gram-positive ( $S$. aureus; $10 \pm 0.2$ $\mathrm{mm}$ ) bacterial strains compared with Gram-negative (E. coli; $9.2 \pm 0.2 \mathrm{~mm}$ ) bacterial strains at $400 \mathrm{ppm}$ concentration. For fungal strain, Ls-Ag NPs have been observed maximum zone of inhibition ( $A$. niger; $6.1 \pm 0.2 \mathrm{~mm})$ at $400 \mathrm{ppm}$ concentration.

Table 2: Antimicrobial activity of Ee-Ls, $\mathrm{Ag}_{2} \mathrm{O}$, and $\mathrm{Ls}-\mathrm{Ag}$ NPs against different antimicrobial organisms

\begin{tabular}{|c|c|c|c|c|c|c|c|}
\hline Test organis ms & $\begin{array}{l}\text { Different concentra } \\
\text { tions }(\mathrm{ppm})\end{array}$ & Ee-Ls (mm) & $\mathrm{Ag}_{2} \mathrm{O}(\mathrm{mm})$ & Ls-Ag NPs (mm) & Ciprofl oxacin & $\begin{array}{l}\text { Flucon azole } \\
\text { (100 ppm) }\end{array}$ & $\begin{array}{r}\text { DMSO } \\
(100 \mathrm{ppm})\end{array}$ \\
\hline & & & & Zone of inhibition & & & \\
\hline \multirow{4}{*}{$\begin{array}{l}\text { Bacterial strains } \\
\text { E. coli }\end{array}$} & & & & & & & \\
\hline & 100 & $0.9 \pm 0.1$ & $4 \pm 0.2$ & $7.9 \pm 0.2$ & $15 \pm 0.3$ & --- & NO \\
\hline & 200 & $2.7 \pm 0.2$ & $3.8 \pm 0.2$ & $8 \pm 0.2$ & & & \\
\hline & 400 & $3.5 \pm 0.2$ & $5.6 \pm 0.2$ & $9.2 \pm 0.2$ & & & \\
\hline \multirow[t]{3}{*}{ S. aureus } & 100 & $2 \pm 0.2$ & $3.6 \pm 0.2$ & $7.5 \pm 0.2$ & $15 \pm 0.3$ & --- & NO \\
\hline & 200 & $3.9 \pm 0.2$ & $5 \pm 0.2$ & $8.7 \pm 0.2$ & & & \\
\hline & 400 & $5.7 \pm 0.2$ & $7.3 \pm 0.2$ & $10 \pm 0.2$ & & & \\
\hline \multicolumn{8}{|l|}{ Fungal strains } \\
\hline \multirow[t]{3}{*}{ A. niger } & 100 & $0.5 \pm 0.1$ & $1.5 \pm 0.2$ & $4 \pm 0.1$ & --- & $9.5 \pm 0.2$ & NO \\
\hline & 200 & $2.5 \pm 0.1$ & $3.5 \pm 0.1$ & $5.7 \pm 0.1$ & & & \\
\hline & 400 & $3.4 \pm 0.2$ & $4.3 \pm 0.2$ & $6.1 \pm 0.2$ & & & \\
\hline
\end{tabular}

'NO'-not observed

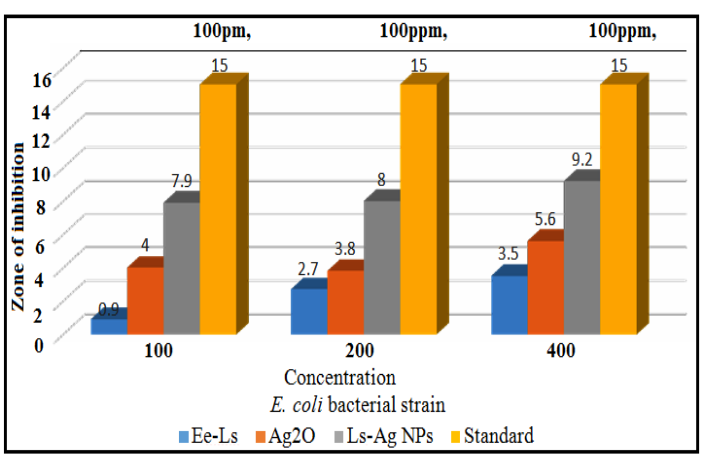

3a

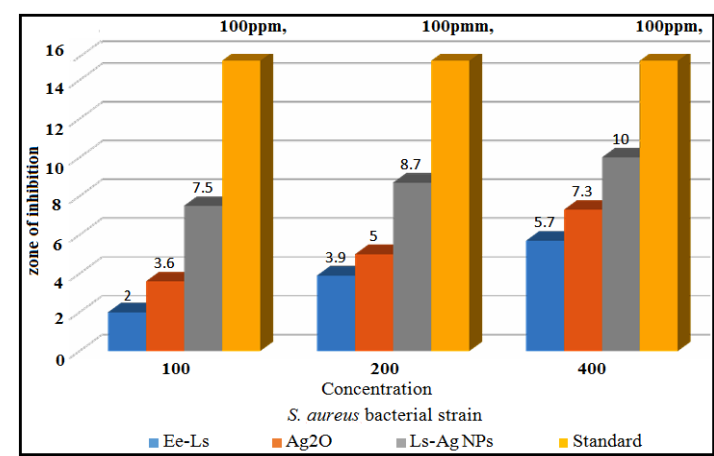

$3 \mathbf{b}$ 


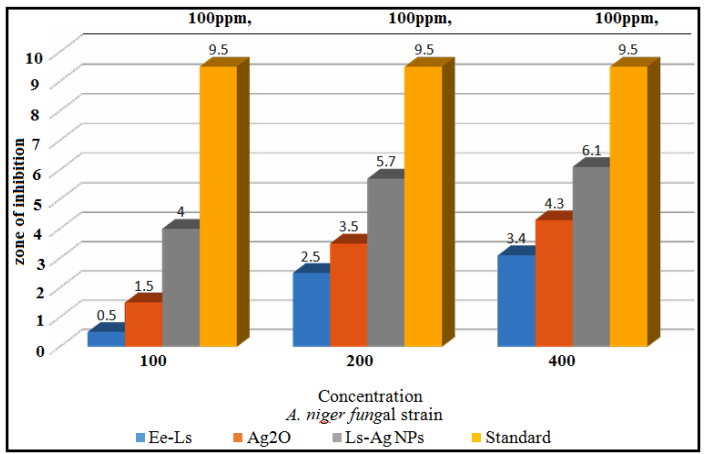

3c

Fig. 3. Histogram of Antimicrobial activity of Ee-Ls, $\mathbf{A g}_{2} \mathrm{O}$, and Ls-Ag NPs against different antimicrobial organisms (3a) E. coli; (3b) S. aureus; (3c) A. niger

\section{DISCUSSION}

In the present study, the prelims phytochemicals i.e., carbohydrates, phenols, proteins, saponins, and tannins have been observed in Ee-Ls while alkaloids, Fats/oils, flavonoids, glycosides, steroids, terpenoids have been found to be absent ${ }^{39-41}$. The secondary metabolites quantified in this analysis have a great deal of biological effects and pharmacological properties ${ }^{49}$. These prelims phytochemicals have been observed from the different parts (fruits, leaves and roots) of L. speciosa ${ }^{53-55}$. Therefore, the carbohydrates, phenols, proteins, saponins and tannins present in Ee-Ls are the most effective biomolecule in synthesis of Ls-Ag NPs ${ }^{50,51 .}$

The morphology of Ls-Ag NPs has been observed by HRTEM analysis. The Ls-Ag NPs have been detected the eclipse in shape with 50-60 nm of average particle size. The prelims constituent's viz. carbohydrates, phenols, proteins, saponins, and tannins have been reported as potential reducing/ stabilizing agent in the synthesis of Ls-Ag NPs ${ }^{47,48}$. According to Saraswathi and Santhakumar (2017), the presence of tannins will help to cap the zirconium oxide nanoparticles and shown photocatalytic activity $^{37}$. Likewise, the carbohydrates content reflects the capping properties of the extract ${ }^{52}$. Saraswathi et al.,(2017) have been reported that the formation of silver nanoparticles by using secondary metabolites (tannins, phenols and flavonoids) which act as a reducing agent during synthesis and shown biofilm activity against selected Pseudomonas aeruginosa clinical strains ${ }^{35}$.
The surface texture and morphology of synthesis Ls-Ag NPs have been explained by using the FESEM analysis. The SEM images have been gathered on to the surface due to the hydrogen bond and electrostatic interactions between the bio-organic capping molecules bound to the $\mathrm{Ls}-\mathrm{Ag}$ $\mathrm{NPs}^{56}$. Similar spectacle has been reported, where the SEM morphology shows crystalline spherical Ag NPs ${ }^{34}$.

The antimicrobial activity of synthesis LsAg NPs compared with $\mathrm{Ag}_{2} \mathrm{O}$ (uncapped Ee-Ls) and Ee-Ls against selected two bacterial strains i.e., Staphylococcus aureus (Gram-positive) and Escherichia coli (Gram-negative) and one fungal strain viz. Aspergillus niger. Result shows that the synthesis Ls-Ag NPs have been enhanced antimicrobial activity than $\mathrm{Ag}_{2} \mathrm{O}$ and Ee-Ls, similar result has been observed by Elumalai and Velmurugan $(2015)^{57}$. The possible reason due to the activity depends on the particle size, morphology, specific surface area and presence of phytochemicals components. In green synthesized Ls-Ag NPs, Ee-Ls fruits act as capping agent surround around the Ls-Ag NPs to reduce the size of particles and enriches the antimicrobial properties of particles ${ }^{58}$. Sundararajan and kumara (2014) have been reported that the synthesized Ag NPs showed more effective antimicrobial results than that of the L. speciosa leaves extract ${ }^{34}$. Hence, we can say that the synthesis Ls-Ag NPs are the useful and effective agent against bacterial and fungal pathogens, which will be more specific and cost-effective.

\section{CONCLUSION}

In summary, the silver nanoparticles have been synthesised by using the green method. The analysis of secondary metabolites has revealed the presence of carbohydrates, phenols, proteins, saponins and tannins in ethanolic extract of fruits of $L$. speciosa (Ee-Ls). These metabolites act as reducing agents, thereby these reduce the metal ions into nanoparticles (Ls-Ag NPs) in environment friendly manner while Ee-Ls stabilises the nanoparticles and hence belongs to green synthesis method. Their morphological studies have 
revealed particles size of $50-60 \mathrm{~nm}$ with eclipsed shape. The biosynthesized Ls-Ag NPs possess much effective antimicrobial activities against two bacterial strains: Staphylococcus aureus (Grampositive) and Escherichia coli (Gram-negative) and one fungal strain: Aspergillus niger as compared to Ee-Ls and $\mathrm{Ag}_{2} \mathrm{O}$. These findings seem to be imperative from environmental, pharmaceutical and therapeutic point of view.

\section{ACKNOWLEDGEMENT}

We would like to thank Maharishi Markandeshwar Education Trust-Ambala (Haryana), India for their support in all respect.

\section{Conflict of interest}

The authors declare that they have read policy and guidelines of the journal and there is no conflict of interest.

\section{REFERENCES}

1. Ahamed, M.; Khan, M. M.; Siddiqui, M. K.; AISalhi, M. S.; Alrokayan, S. A. Green synthesis, characterization and evaluation of biocompatibility of silver nanoparticles, Physica E Low Dimens. Syst. Nanostruct., 2011, 43(6), 1266-1271.

2. Roy, A. Synthesis of silver nanoparticles from medicinal plants and its biological application: a review, Res. Rev. BioSci., 2017, 12(4), 138.

3. Narayanan, K. B.; Sakthivel, N. Biological synthesis of metal nanoparticles by microbes., Adv. Colloid. Interface. Sci., 2010, 156, 1-13.

4. Krolikowska, A.; Kudelski, A.; Michota, A.; Bukowska, J. SERS Studies on the structure of thioglycolic acid monolayers on silver and gold, Surf. Sci., 2003, 532, 227-232.

5. Park, J.; Joo, J.; Kwon, S.; Jang, Y.; Hyeon, T. Synthesis of monodisperse spherical nanocrystals., Angew. Chem. Int., 2007, 46, 4630-4660.

6. Ma, X.; Zhao, Y,; Liang, X. Theranostic nanoparticles engineered for clinic and pharmaceutics., Acc. Chem. Res., 2011, 44, 1114-122.

7. Ocsoy, I.; Gulbakan, B.; Shukoor, M. I.; Xiong, X.; Chen, T.; Powell, D.H.; Tan, W. Aptamerconjugated multifunctional nanoflowers as a platform for targeting, capture, and detection in laser desorption ionization mass spectrometry., ACS Nano., 2013, 7, 417-427.

8. Cheon, J.; Kang, N. J.; Lee, S.M.; Lee, J.H.; Yoon, J. H.; Jun Oh, S. Shape evolution of single-crystalline iron oxide nanocrystals., J. Am. Chem. Soc., 2004, 126, 1950-1951.

9. Schladt, T. D.; Graf, T.; Tremel, W. Synthesis and characterization of monodisperse manganese oxide nanoparticles-evaluation of the nucleation and growth mechanism. Chem. Mater., 2009, 21, 3183-3190.

10. Bhattacharya, D.; Rajinder, G. Nanotechnology and potential of microorganisms. Crit. Rev. Biotechnol., 2005, 25, 199-204.

11. Jana, N. R.; Wang, Z. L.; Sau, T. K.; Pal, T. Seed-mediated growth method to prepare cubic copper nanoparticles., Curr. Sci., 2000, 79, 1367-1370.

12. Raveendran, P.; Fu, J.; Wallen, S. L. Completely "green" synthesis and stabilization of metal nanoparticles., J. Am. Chem. Soc., 2003, 125, 13940-13941.

13. Iravani, S. Green synthesis of metal nanoparticles using plants., Green Chem., 2011, 13, 2638- 2650.

14. Duman, F.; Ocsoy, I.; Ozturk Kup, F. Chamomile flower extract-directed $\mathrm{CuO}$ nanoparticle formation for its antioxidant and DNA cleavage properties., Mater. Sci. Eng. C., 2016, 60, 333-338.

15. Duran, N.; Marcato, P. D.; Alves, O. L.; De souza, G. I. Esposito E. Mechanistic aspects of biosynthesis of silver nanoparticles by several Fusarium oxysporum strains., J. Nanobiotechnology., 2005, 3, 1-17.

16. Elahi, N.; Kamali, M.;Baghersad, M. H. Recent biomedical applications of gold nanoparticles: A review., Talanta., 2018, 184, 537-556.

17. Nakkala, J. R.; Bhagat, E.; Suchiang, K.; Sadras, S. R. Comparative study of antioxidant and catalytic activity of silver and gold nanoparticles synthesized from Costus pictus leaf extract., J. Mater. Sci. Technol., 2015, 31(10), 986-994.

18. Prakash, V.; Kaur, H.; Kumari, A.; Kumar, M.; Bala, R.; Gupta, S. Phytochemicals and biological studies on Cycas revoluta Thunb.: a review., Adv. Tradit. Med. 2020. https://doi. org/10.1007/s13596-020-00520-z.

19. Prakash, V.; Kumari, A Kaur H, Kumar M, Gupta S, Bala R. Chemical Constituents and Biological Activities of Genus Picrorhiza: An Update. Indian J Pharm Sci., 2020, 82(4), 562-577. 
20. Geetha, T. S.; Geetha, N. Phytocjemical screening, qualitative analysis from Kodaikanal hills, Tamilnadu., Int. J. Pharmtech. Res., 2014, 6(2), 187-204.

21. Aromal, S. A.; Philip, D. Green synthesis of gold nanoparticles using Trigonella foenumgraecum and its size dependent catalytic activity., Spectrochim. Acta A Mol. Biomol. Spectrosc., 2012, 97, 1-5.

22. Narayanan, K. B.; Sakthivel, N. Biological synthesis of metal nanoparticles by microbes., Adv. Colloid. Interfac. Sci. 2010, 156, 1-13.

23. Kim, J. S.; Kuk, E.; Yu, K. N.; Kim, J. H.;Park, S. J.; Lee, H. J.; Kim, S. H.; Park, Y. K.; Park, Y. H.; Hwang, C. Y.; Kim, Y. K. Antimicrobial effects of silver nanoparticles., Nanomedicine: NBM., 2007, 3(1), 9 5-101.

24. Rajan, R.; Chandran, K.; Harper, S. L.; Yun, S. I.; Kalaichelvan, P. T. Plant extract synthesized silver nanoparticles: an ongoing source of novel biocompatible materials., Ind. Crops. Prod., 2015, 70, 356-373.

25. Chahar, V.; Sharma, B.; Shukla, G.; Srivastava, A.; Bhatnagar, A. Study of antimicrobial activity of silver nanoparticles synthesized using green and chemical approach., Colloids Surf., A Physicochem. Eng. Asp., 2018, 554, 149-155.

26. Bar, H.; Bhui, D. K.; Sahoo, G. P.; Sarkar, P.; De, S. P.; Misra, A. Green synthesis of silver nanoparticles using latex of Jatropha curcas., Colloids Surf., A Physicochem. Eng. Asp., 2009, 339(1-3), 134-139.

27. Shafaghat, A. Synthesis and characterization of silver nanoparticles by phytosynthesis method and their biological activity., Synth. React. Inorg. M., 2015, 45(3), 381-387.

28. Zayed, M. F.; Mahfoze, R. A.; El-kousy, S. M.; Al-Ashkar, E. A. In-vitro antioxidant and antimicrobial activities of metal nanoparticles biosynthesized using optimized Pimpinella anisum extract., Colloids Surf., APhysicochem. Eng. Asp., 2020, 585, 124167.

29. Das, P. E.; Abu-Yousef, I. A.; Majdalawieh, A. F.; Narasimhan, S.; Poltronieri, P. Green synthesis of encapsulated copper nanoparticles using a hydroalcoholic extract of Moringa oleifera leaves and assessment of their antioxidant and antimicrobial activities., Molecules. 2020, 25(3), 555.
30. AISalhi, M. S.; Elangovan, K.; Ranjitsingh, A. J.; Murali, P.; Devanesan, S. Synthesis of silver nanoparticles using plant derived 4-N-methyl benzoic acid and evaluation of antimicrobial, antioxidant and antitumor activity., Saudi. J. Biol. Sci., 2019, 26(5), 970- 978.

31. Rohit Singh, T.; Ezhilarasan, D. Ethanolic extract of Lagerstroemia speciosa (L.) Pers., induces apoptosis and cell cycle arrest in HepG2 cells., Nutr. Cancer., 2020, 72(1), 146-156.

32. Nasrin, F.; Ahmad, S. Evaluation of antimicrobial, antioxidant and cytotoxic activities of methanolic extracts of Lagerstroemia speciosa leaves and barks., J. Appl. Pharm. Sci., 2012, 2(10), 142-147.

33. Rahman, M. A.; Uddin, N.; Hasanuzzaman, M.; Rahman, A. A. Antinociceptive, antidiarrhoeal and cytotoxic activities of Lagerstroemia speciosa (L.) pers. Pharmacologyonline., 2011, 2011(1), 604-612.

34. Sundararajan, B.; Kumari, B. R. Biosynthesis of silver nanoparticles in Lagerstroemia speciosa (L) pers and their antimicrobial activities., Int. J. Pharm. Pharm. Sci., 2014, 6(3), 30-34.

35. Saraswathi, V. S.; Kamarudheen, N.; BhaskaraRao, K. V.; Santhakumar, K. Phytoremediation of dyes using Lagerstroemia speciosa mediated silver nanoparticles and its biofilm activity against clinical strains Pseudomonas aeruginosa., J. Photochem Photobiol. B., 2017, 168, 107-116.

36. Saisaraswathi, V.; Tatsugi, J.; Shin, P. K.; Santhakumar, K. Facile biosynthesis, characterization and solar assisted photocatalytic effect of $\mathrm{ZnO}$ nanoparticles mediated by leaves of $L$. speciosa. $\mathrm{J} J$. Photochem Photobiol. B., 2017, 167, 89-98.

37. Saisaraswathi, V.; Santhakumar, K. Photocatalytic activity against azo dye and cytotoxicity on MCF-7 cell lines of zirconium oxide nanoparticle mediated using leaves of Lagerstroemia speciosea. J. Photochem Photobiol. B., 2017, 169, 47-55.

38. Mukherjee, P. K. Quality Control of Herbal Drugs. An approaches to evaluation of botanicals. Edn $1^{\text {st }}$. Business Horizons. New Delhi., 2002, 390-403.

39. Kaur, H.; Kumari, A.; Kumar, M.; Sachdeva, D.; Bala, R.; Prakash, V. Phytochemicals Analysis of Sarcotesta Layer of Cycas revoluta Thunb. Fruit through GC-MS., Int. J. Adv. Sci. Technol., 2020, 29(8), 5111-5118. 
40. Lahlou, M. Methods to study the phytochemistry and bioactivity of essential oils., Phytother. Res., 2004, 18(6), 435-448.

41. Adetuyi, A. O.; Popoola, A. V. Extraction and dye's ability potential studies of the colourant in zanthoxylum zanthoxyloides plant on cotton fabric., J. Sci. Eng. Technol., 2001, 8(2), 3291-3299.

42. Yong, N. L.; Ahmad, A.; Mohammad, A. W. Synthesis and characterization of silver oxide nanoparticles by a novel method., Int. J. Sci. Eng. Res., 2013, 4(5), 155-158.

43. Mukherjee, P. K.; Balasubramanian, P.; Saha, K.; Saha, B. P.; Pal, M. Antibacterial efficiency of Nelumbo nucifera (Nymphaeaceae) rhizomes extract., Indian Drugs., 1995, 32, 274-276.

44. Bagamboula, C. F.; Uyttendaela, M.; Devere, J. Inhibitory effect of Thyme and basil essential oil, carvacrol, thymol, estragol, inalool and p-cymene towards Shigella sonnei and S. flexnerii., Food Microbiol., 2004, 21, 33-42.

45. Ajiboye, A. E.; Olawoyin, R. A. Antibacterial activities and phytochemical screening of crude extract of Carica papaya leaf against selected pathogens., Global J. Pure App. Sci., 2020, 26(2), 165-170.

46. Toit, D. E.A.; Rautenbach, M. A sensitive standardised micro-gel well diffusion assay for the determination of antimicrobial activity., J. Microbiol. Methods., 2000, 42(2), 159-165.

47. Kavitha, R.; Kamalakannan, P.; Deepa, T.; Elamathi, R.; Sridhar, S.; Suresh Kumar, J. In vitro antimicrobial activity and phytochemical analysis of Indian medicinal plant Couroupita guianensis Aubl., J. Chem. Pharm. Res., 2011, 3(6), 15-121.

48. Juvekar, M.; Juvekar, A.; Kulkarni, M.; Wakade, A.; Ambaye, R.; Wankhede, S. Phytochemical and pharmacological studies on the leaves of Couroupita guianensis Aubl. Planta Medica., 2009, 75(09), PJ168.

49. Laruan, L. M. V.; Balangcod, T.; Balangcod, K.; Patacsil, M.; Apostol, O.; Manuel, J.; Cortez, S.;Vallejo, V. Phytochemical and antibacterial study of Lagerstroemia speciosa (L.) Pers. and its ethnomedicinal importance to indigenous communities of Benguet
Province, Philippines., Indian J. Tradit. Knowl., 2013, 12(3), 379-383.

50. Sahu, N.; Soni, D.; Chandrashekhar, B.; Satpute, D. B.; Saravanadevi, S.; Sarangi, B. K.; Pandey, R. A. Synthesis of silver nanoparticles using flavonoids: hesperidin, naringin and diosmin, and their antibacterial effects and cytotoxicity., Int. Nano. Lett., 2016, 6(3), 173- 181.

51. Pettegrew, C.; Dong, Z.; Muhi, M. Z.; Pease, S.; Mottaleb, M. A.; Islam, M. R..Silver nanoparticle synthesis using monosaccharides and their growth inhibitory activity against Gramnegative and positive bacteria., Int. Sch. Res. Notices., 2014, 2014, 1-8.

52. Sharma, V. K.; Yngard, R. A.; Lin, Y. Silver nanoparticles: green synthesis and their antimicrobial activities., Adv. Colloid. Interfac. Sci., 2009, 145(1-2), 83-96.

53. Azad, A. K.; Azizi, W. S.; Ismail, A. F.; Abbas, S. A.; Uddin, J.; Labu, Z. K. Phytochemical and Toxicity Evaluation of Traditional Herb: Lagerstroemia speciosa L.(Banaba) by MCF-7 Cell Line and Brine Shrimp Lethality Bioassay., Bangladesh Pharm. J., 2019, 22(1), 45-49.

54. Bellah, S. F.; Islam, K. M.; Karim, M. R.; Hossain, M. J.; Ashrafudoulla, M.; Hasan, M. Phytochemical and Pharmacological Screening of the fruits of Lagerstroemia speciosa (L.) pers. World J. Pharm. Sci., 2016, 4(5), 205-211.

55. Saraswathi, V. S.; Thirumalai, D.; Yadav, P. K.; Saranya, M. Pharmacognostic and preliminary phytochemical study of Lagerstroemia speciosa leaves. Int. J. Res. Ayurveda Pharm., 2011, 2(3), 893-898.

56. Priya, M. M.; Selvi, B. K.; Paul, J. A. Green synthesis of silver nanoparticles from the leaf extracts of Euphorbia hirta and Nerium indicum. Dig. J. Nanomater. Bios., 2011, 6(2), 869-877.

57. Elumalai, K.; Velmurugan, S. Green synthesis, characterization and antimicrobial activities of zinc oxide nanoparticles from the leaf extract of Azadirachta indica (L.). Appl. Surf. Sci., 2015, 345, 329-336. 